\title{
Extracellular Proteome Analysis Shows the Abundance of Histidine Kinase Sensor Protein, DNA Helicase, Putative Lipoprotein Containing Peptidase M75 Domain and Peptidase C39 Domain Protein in Leptospira interrogans Grown in EMJH Medium
}

\author{
Abhijit Sarma ${ }^{1}$, Dhandapani Gunasekaran 1,2, Devasahayam Arokia Balaya Rex ${ }^{3}$, Thoduvayil Sikha ${ }^{1,4}$, \\ Homen Phukan 1 ${ }^{(D)}$, Kumar Mangalaparthi Kiran ${ }^{5,6}$, Sneha M. Pinto ${ }^{3,5}$, \\ Thottethodi Subrahmanya Keshava Prasad ${ }^{3,5,6}$ (D) and Madathiparambil G. Madanan 1,*(D)
}

check for

Citation: Sarma, A.; Gunasekaran,

D.; Rex, D.A.B.; Sikha, T.; Phukan, H.;

Kiran, K.M.; Pinto, S.M.; Prasad,

T.S.K.; Madanan, M.G. Extracellular

Proteome Analysis Shows the Abundance of Histidine Kinase Sensor Protein, DNA Helicase, Putative Lipoprotein Containing Peptidase M75 Domain and Peptidase C39 Domain Protein in Leptospira interrogans Grown in EMJH Medium. Pathogens 2021, 10, 852. https://doi.org/

Academic Editors: Sreekumari Rajeev and Alejandro Llanes

Received: 30 May 2021

Accepted: 4 July 2021

Published: 6 July 2021

Publisher's Note: MDPI stays neutral with regard to jurisdictional claims in published maps and institutional affiliations.

Copyright: (C) 2021 by the authors. Licensee MDPI, Basel, Switzerland. This article is an open access article distributed under the terms and conditions of the Creative Commons Attribution (CC BY) license (https:/ / creativecommons.org/licenses/by/ $4.0 /)$.
1 Regional Medical Research Centre Port Blair, Indian Council of Medical Research Port Blair 744103, Andaman and Nicobar Islands, India; abhijit.sarma2012@gmail.com (A.S.); gunasekaran.vpm1990@gmail.com (D.G.); sikha.tt@gmail.com (T.S.); biotechphukan16@gmail.com (H.P.)

2 Department of Chemical Sciences, Ariel University, Ariel 70400, Israel

3 Center for Systems Biology and Molecular Medicine, Yenepoya (Deemed to be University), Mangalore 575018, India; rexprem@yenepoya.edu.in (D.A.B.R.); sneha.mp@gmail.com (S.M.P.); tskprasad@gmail.com (T.S.K.P.)

4 Department of Pathology, Jawaharlal Institute of Postgraduate Medical Education and Research, Puducherry 605006, India

5 Institute of Bioinformatics, Bangalore 560066, India; mkirankumar45@gmail.com

6 NIMHANS-IOB Proteomics and Bioinformatics Laboratory, Neurobiology Research Centre, National Institute of Mental Health and Neuro Sciences, Bangalore 560029, India

* Correspondence: madanan.mg@icmr.gov.in or madananmg@gmail.com

\begin{abstract}
Leptospirosis is a re-emerging form of zoonosis that is caused by the spirochete pathogen Leptospira. Extracellular proteins play critical roles in the pathogenicity and survival of this pathogen in the host and environment. Extraction and analysis of extracellular proteins is a difficult task due to the abundance of enrichments like serum and bovine serum albumin in the culture medium, as is distinguishing them from the cellular proteins that may reach the analyte during extraction. In this study, extracellular proteins were separated as secretory proteins from the culture supernatant and surface proteins were separated during the washing of the cell pellet. The proteins identified were sorted based on the proportion of the cellular fractions and the extracellular fractions. The results showed the identification of 56 extracellular proteins, out of which 19 were exclusively extracellular. For those proteins, the difference in quantity with respect to their presence within the cell was found to be up to 1770 -fold. Further, bioinformatics analysis elucidated characteristics and functions of the identified proteins. Orthologs of extracellular proteins in various Leptospira species were found to be closely related among different pathogenic forms. In addition to the identification of extracellular proteins, this study put forward a method for the extraction and identification of extracellular proteins.
\end{abstract}

Keywords: Leptospira; protein; extracellular; surface; secretory; pathogenic; proteomics

\section{Introduction}

Leptospirosis, the zoonotic disease once confined to posing a risk during agricultural activities, has been re-emerging due to increasing urbanization and slum areas that have increased the reservoir rodent population [1]. The increase in outbreaks during floods has been due to water getting contaminated with the urine from rats and several other domestic and wild animals that spread out during the floods. Humans exposed to such 
water obtain the infection through cuts, wounds, and abrasions on the skin. Symptoms of leptospirosis appear after two weeks of infection and progress rapidly. Early diagnosis and treatment form the most important strategy to avoid complications and the loss of life due to leptospirosis. Alternatively, the development of efficient vaccines and drugs is also necessary. Rational development of diagnostic tools and vaccines requires a clear understanding of the molecules used as candidates or targets for this purpose [2]. Secretory proteins are a group of molecules from which better molecules for an anti-leptospiral strategy can be obtained because of their biological significance concerning pathogenesis and host-pathogen interactions [3]. Many pathogens secrete toxins, proteases, and a range of extracellular enzymes like lipase, fibrinolysin, hyaluronidase, protease, elastase, etc. [4-6].

It has been shown that there are many protease activities that can degrade the extracellular matrix and plasma proteins to contribute to the process of infection and pathogenesis in the culture supernatant of L. interrogans [7]. One of the earliest studies indicated the secretion of $60 \mathrm{kDa}$ hemolysin, which was found to be inducing proinflammatory cytokines through the Toll-like receptor 2-and 4-mediated JNK and NF- KB signaling pathways [8,9]. Hemolysin and sphingomyelinase activity has been detected in the culture fluids of several strains of pathogenic Leptospira with specific antiserums [10-12]. Many immunoreactive proteins have been reported from acute and convalescent-phase sera of leptospirosis patients $[13,14]$. The Staphylococcus aureus secretes a variety of immune evasion molecules, including proteases that cleave components of the innate immune system and also disrupt the integrity of the extracellular matrix. The secretory proteins of $S$. aureus can activate host zymogens that target host-specific defense and inhibit the anti-bacterial functions of the host, thereby enhancing the chances of pathogen survival in the host [15]. A secreted protein kinase YpkA of Yersinia pseudotuberculosis is involved in pathogenicity by interfering with the signal transduction pathways of the host cell [16]. The Coxiella burnetii secretes Coxiella serine/threonine-protein kinase (CstK) that functions as a bacterial effector protein and assists in the biogenesis of parasitophorous vacuole and replication of the intracellular pathogen by interacting with the host protein TBC1D5 [17]. The involvement of secretory proteins in invasion and pathogenesis is also well established in many parasite infections. In Toxoplasma gondii, invasion and replication in the host is facilitated by secretory proteins by the modification of host cellular factors [18], which are governed by the parasite proteins secreted from their secretory organelles like rhoptries and dense granules [19].

Secretory proteins are good diagnostic targets during infection and can be a direct indicator of pathogen load in the host $[20,21]$. However, the difficulty of their isolation and purification of secretory proteins from biological samples, as well as culture supernatants, has restricted the research and exploration of their use in anti-leptospirosis strategies. The main reason for this is that many forms of culture media are very rich in proteins and are used as forms of enrichment in the medium, which makes the isolation of secretory proteins difficult. For example, the isolation of secretory proteins from culture supernatant containing abundant Bovine Serum Albumin (BSA) $(10 \mathrm{mg} / \mathrm{mL})$ present in the Ellinghausen-McCullough-Johnson-Harris (EMJH) medium, used to culture Leptospira, is a challenging process. In this context, a multipronged approach coupled with the enrichment of secretory proteins from culture supernatant, its analysis using high throughput Liquid Chromatography with tandem Mass Spectrometry (LC-MS/MS) based proteomics, and the use of bioinformatics tools for the selection of candidate proteins from the supernatant of Leptospira culture in complete EMJH medium was attempted. Previously, Triton X-114 fractionation coupled with LC-MS/MS-based proteomics to determine OMPs of L. interrogans [22] was used to compare the cellular portion with the extracellular proteins from the wash and supernatant of the culture identified through LC-MS/MS in this study. This article describes the enrichment of secretory proteins from the EMJH culture supernatant and surface proteins from the wash fraction and the proteomic and bioinformatics analysis of the results. 


\section{Results}

LC-MS/MS analysis of TritonX-114 fractions of L. interrogans serovar Copenhageni strain Fiorcruz L1-130 and subsequent identification yielded 2425 proteins in aqueous fractions, 2646 protein in detergents, and 1684 proteins in a pellet that comprised 2957 unique proteins reported under the ProteomeXchange dataset identifiers PXD009050 and PXD016204 [22]. The analysis of wash and supernatant identified 837 proteins in wash 851 proteins in the supernatant comprising 1176 unique proteins (Figure 1A). The proteomics dataset is available through ProteomeXchange with the identifier PXD026044.
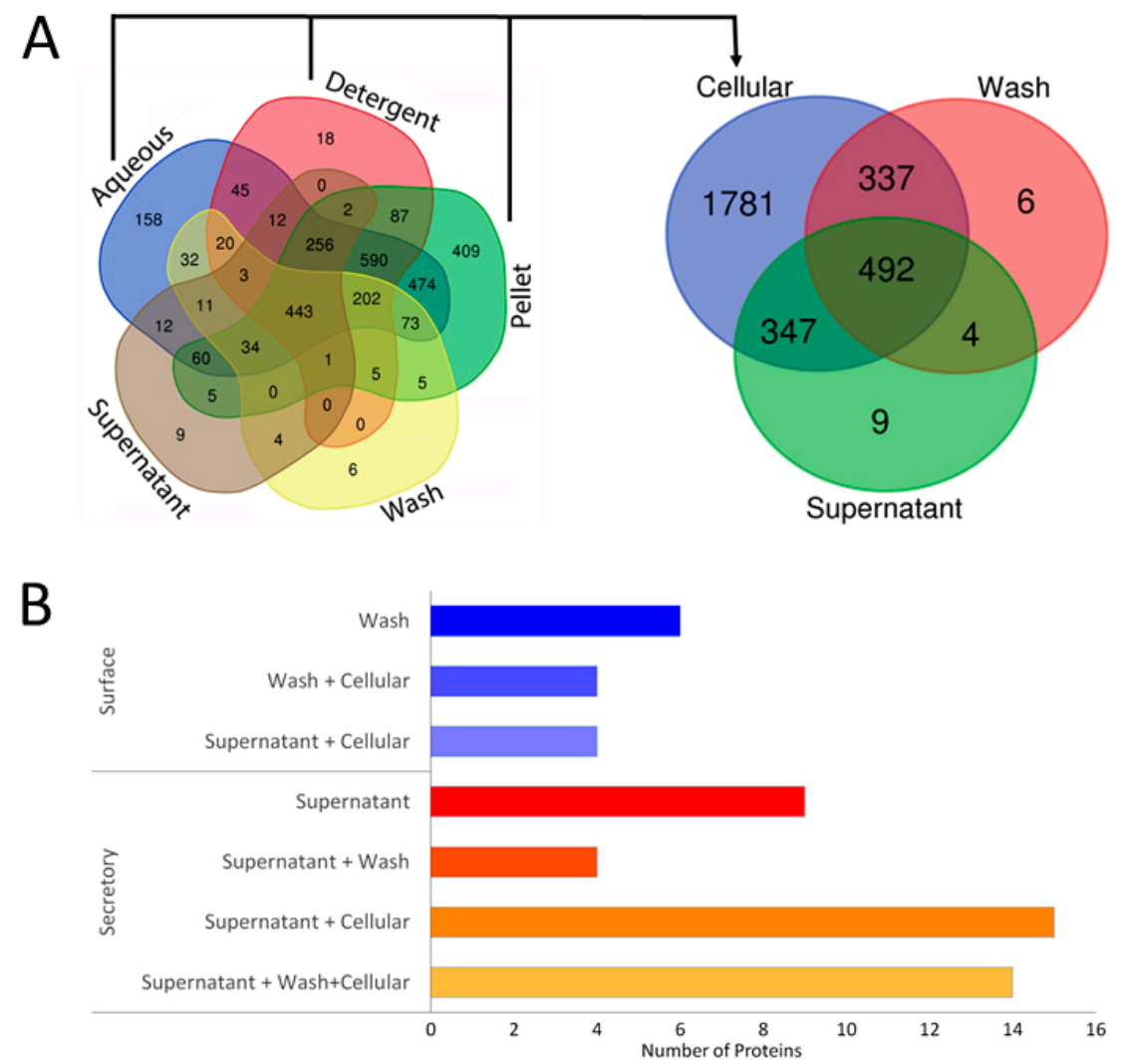

Figure 1. Mass spectrometry of leptospiral proteins. The Venn diagram shows the distribution of proteins identified from the Leptospira (A) culture pellet that was fractionated using Triton X-114 (aqueous, detergent, and pellet), the culture 'supernatant' obtained after centrifugation and pool of three washes, with PBS containing $5 \mathrm{mM} \mathrm{MgCl}$, of the pellet designated as 'wash' as well as the merged Triton X-114 fractions designated as the 'cellular' protein. (B) Shows iBAQ based abundance of 56 unique extracellular proteins distributed in the wash (surface) and supernatant (secreted).

The abundance of secretory proteins across aqueous, detergent, pellet, wash, and supernatant fractions was calculated based on Intensity-Based Absolute Quantification (iBAQ) values (Table 1 and Supplementary Table S1). A protein was considered abundant in a fraction if the average $\mathrm{iBAQ}$ value of the protein from three replication was at least 1.5-fold higher than the average iBAQ value of the protein totaled out of all other fractions. This showed that 56 proteins were abundant out of 1176 proteins identified in the wash and supernatant together. Out of the 56 proteins, 19 were not found in cellular fractions (aqueous, detergent, and pellet proteins together). Out of the 19 proteins, six were found only in the wash fraction (surface), nine were found exclusively in the supernatant (secretory), and four were found in both with an abundance in the supernatant (Figure 1B). 
Table 1. Abundance based sorting of extracellular proteins using iBAQ values. Selection of 56 extracellular out of 1195 proteins identified through LC-MS/MS in wash and supernatant of Leptospira grown in EMJH medium. The values shown are average of normalized iBAQ values from three replicates. The abundance is indicated as exclusively present in wash (Ex. W), exclusively present in supernatant (Ex. S), and present only in wash, while supernatant (Ex. EC) and those found in cellular fractions also are shown in values indicating a fold of abundance as being extracellular. The protein is not identified in the fraction (-). The proteins found abundant in the cellular fractions are submitted as Supplementary Table S1.

\begin{tabular}{|c|c|c|c|c|c|c|c|}
\hline Sl. No. & Accession & $\begin{array}{l}\text { Gene Names } \\
\text { (Ordered Locus) }\end{array}$ & Description & $\begin{array}{l}\text { Total Value of } \\
\text { Triton X-114 } \\
\text { Fractions (C) }\end{array}$ & $\begin{array}{l}\text { Wash (W) } \\
\text { (Surface) }\end{array}$ & $\begin{array}{l}\text { Supernatant (S) } \\
\text { (Secretory) }\end{array}$ & $\begin{array}{c}\text { Abundance of } \\
\text { Extracellular } \\
\text { Proteins (EC) }= \\
(W+S) / C\end{array}$ \\
\hline 1 & WP_000286526.1 & & hypothetical protein & - & 0.1 & - & Ex. W \\
\hline 2 & WP_000424814.1 & & ComF family protein & - & 8.4 & - & Ex. W \\
\hline 3 & WP_000486779.1 & LIC_10697 & hypothetical protein & - & 2.2 & - & Ex. W \\
\hline 4 & WP_000700529.1 & & hypothetical protein & - & 0.5 & - & Ex. W \\
\hline 5 & WP_000865345.1 & LIC_13053 & fatty acid desaturase & - & 0.3 & - & Ex. W \\
\hline 6 & WP_001973446.1 & & hypothetical protein & - & 0.7 & - & Ex. W \\
\hline 7 & WP_000371179.1 & LIC_13177 & hypothetical protein & - & - & 5.9 & Ex. S \\
\hline 8 & WP_000416054.1 & LIC_11345 & $\begin{array}{l}\text { TonB-dependent } \\
\text { siderophore receptor }\end{array}$ & - & - & 0.04 & Ex. S \\
\hline 9 & WP_000738678.1 & LIC_12988 & lipase & - & - & 14.3 & Ex. S \\
\hline 10 & WP_000812418.1 & LIC_10645 & hypothetical protein & - & - & 1.4 & Ex. S \\
\hline 11 & WP_000844347.1 & LIC_10346 & $\begin{array}{c}\text { SGNH/GDSL } \\
\text { hydrolase family } \\
\text { protein }\end{array}$ & - & - & 1.2 & Ex. S \\
\hline 12 & WP_000899352.1 & & $\begin{array}{l}\text { sphingomyelin } \\
\text { phosphodiesterase }\end{array}$ & - & - & 1.7 & Ex. S \\
\hline 13 & WP_001021444.1 & & $\begin{array}{c}\text { DUF1563 } \\
\text { domain-containing } \\
\text { protein }\end{array}$ & - & - & 18.2 & Ex. S \\
\hline 14 & WP_001088866.1 & LIC_12191 & NUDIX hydrolase & - & - & 2.3 & Ex. S \\
\hline 15 & WP_025176658.1 & & hypothetical protein & - & - & 17.3 & Ex. S \\
\hline 16 & WP_000336237.1 & LIC_12715 & $\begin{array}{c}\text { DUF1561 } \\
\text { domain-containing } \\
\text { protein }\end{array}$ & - & 0.7 & 3.2 & Ex. EC \\
\hline 17 & WP_000533970.1 & LIC_12986 & $\begin{array}{c}\text { DUF1561 } \\
\text { domain-containing } \\
\text { protein }\end{array}$ & - & 0.5 & 3.9 & Ex. EC \\
\hline 18 & WP_001193644.1 & & hypothetical protein & - & 2.1 & 4.7 & Ex. EC \\
\hline 19 & WP_001211842.1 & LIC_11088 & di-heme enzyme & - & 0.4 & 4.8 & Ex. EC \\
\hline 20 & WP_000433639.1 & LIC_11528 & $\begin{array}{l}\text { PAS domain S-box } \\
\text { protein }\end{array}$ & 0.5 & 941.1 & 7.0 & 1771.4 \\
\hline 21 & WP_000378420.1 & LIC_11624 & ATPase AAA & 21.5 & 813.4 & 1871.9 & 124.9 \\
\hline 22 & WP_001049563.1 & LIC_10713 & peptidase M75 & 23.5 & 11.8 & 1833.1 & 78.5 \\
\hline 23 & WP_001205796.1 & LIC_10511 & hypothetical protein & 0.1 & - & 4.0 & 75.6 \\
\hline 24 & WP_000938871.1 & LIC_20255 & hypothetical protein & 1.7 & 42.3 & 29.6 & 42.5 \\
\hline 25 & WP_000752033.1 & LIC_10370 & hypothetical protein & 2.1 & 10.8 & 72.9 & 38.9 \\
\hline 26 & WP_001071893.1 & LIC_10704 & hypothetical protein & 2.9 & - & 101.8 & 35.2 \\
\hline 27 & WP_000689168.1 & & $\begin{array}{c}\text { SGNH/GDSL } \\
\text { hydrolase family } \\
\text { protein }\end{array}$ & 2.0 & - & 55.3 & 28.0 \\
\hline
\end{tabular}


Table 1. Cont.

\begin{tabular}{|c|c|c|c|c|c|c|c|}
\hline Sl. No. & Accession & $\begin{array}{l}\text { Gene Names } \\
\text { (Ordered Locus) }\end{array}$ & Description & $\begin{array}{l}\text { triton } X-114 \\
\text { ractions (C) }\end{array}$ & $\begin{array}{l}\text { Wash (W) } \\
\text { (Surface) }\end{array}$ & $\begin{array}{l}\text { Supernatant (S) } \\
\text { (Secretory) }\end{array}$ & $\begin{array}{c}\text { Abundance of } \\
\text { Extracellular } \\
\text { Proteins (EC) }= \\
(W+S) / C\end{array}$ \\
\hline 28 & WP_002002492.1 & LIC_11904 & hypothetical protein & 3.3 & - & 86.1 & 26.3 \\
\hline 29 & WP_001010056.1 & & hypothetical protein & 3.6 & - & 94.0 & 26.2 \\
\hline 30 & WP_000141324.1 & LIC_11265 & $\begin{array}{l}\text { MULTISPECIES: } \\
\text { DUF1858 } \\
\text { domain-containing } \\
\text { protein }\end{array}$ & 5.4 & - & 139.8 & 25.9 \\
\hline 31 & WP_000620240.1 & LIC_10371 & hypothetical protein & 12.1 & 2.4 & 246.8 & 20.7 \\
\hline 32 & WP_080011816.1 & & $\begin{array}{l}\text { sphingomyelin } \\
\text { phosphodiesterase }\end{array}$ & 0.4 & - & 7.0 & 19.4 \\
\hline 33 & WP_000806224.1 & LIC_13164 & $\begin{array}{l}\text { 2-amino-4-hydroxy-6- } \\
\text { hydroxymethyldihydropteridine } \\
\text { diphosphokinase }\end{array}$ & 11.1 & 1.0 & 206.8 & 18.6 \\
\hline 34 & WP_000768408.1 & LIC_12891 & hypothetical protein & 2.2 & 1.6 & 35.9 & 16.7 \\
\hline 35 & WP_000680185.1 & LIC_10365 & $\begin{array}{l}\text { DUF1565 } \\
\text { domain-containing } \\
\text { protein }\end{array}$ & 0.6 & 1.3 & 7.6 & 14.7 \\
\hline 36 & WP_000620247.1 & LIC_10373 & hypothetical protein & 4.6 & 2.5 & 65.8 & 14.7 \\
\hline 37 & WP_000564696.1 & LIC_10183 & hypothetical protein & 0.8 & 11.0 & - & 14.4 \\
\hline 38 & WP_000999999.1 & LIC_11240 & $\begin{array}{l}\text { ATP synthase subunit } \\
\text { delta }\end{array}$ & 205.7 & 0.7 & 2731.9 & 13.3 \\
\hline 39 & WP_000696002.1 & LIC_13248 & $\begin{array}{l}\text { DUF1554 } \\
\text { domain-containing } \\
\text { protein }\end{array}$ & 0.7 & - & 8.6 & 12.6 \\
\hline 40 & WP_000092385.1 & LIC_12791 & $\begin{array}{l}\text { DUF1561 } \\
\text { domain-containing } \\
\text { protein }\end{array}$ & 0.6 & - & 6.7 & 11.7 \\
\hline 41 & WP_000019139.1 & LIC_12413 & $\begin{array}{l}\text { DUF115 } \\
\text { domain-containing } \\
\text { protein }\end{array}$ & 3.4 & - & 38.3 & 11.2 \\
\hline 42 & WP_000603280.1 & LIC_20247 & $\begin{array}{l}\text { lytic transglycosylase } \\
\text { domain-containing } \\
\text { protein }\end{array}$ & 0.7 & - & 6.9 & 10.3 \\
\hline 43 & WP_000734588.1 & & hypothetical protein & 11.2 & - & 92.3 & 8.2 \\
\hline 44 & WP_000440098.1 & & $\begin{array}{l}\text { DUF2203 } \\
\text { domain-containing } \\
\text { protein }\end{array}$ & 3.1 & 20.5 & - & 6.6 \\
\hline 45 & WP_000141830.1 & LIC_12540 & $\begin{array}{c}\text { MULTISPECIES: } \\
\text { preprotein translocase } \\
\text { subunit YajC }\end{array}$ & 1067.4 & 1534.6 & 4361.7 & 5.5 \\
\hline 46 & WP_001001307.1 & & hypothetical protein & 0.5 & 2.4 & - & 5.2 \\
\hline 47 & WP_001019268.1 & LIC_12755 & $\begin{array}{c}\text { MULTISPECIES: } \\
\text { hypothetical protein }\end{array}$ & 94.8 & 21.7 & 289.9 & 3.3 \\
\hline 48 & WP_001005911.1 & LIC_10552 & $\begin{array}{l}\text { hybrid sensor histidine } \\
\text { kinase/response } \\
\text { regulator }\end{array}$ & 0.8 & - & 2.7 & 3.2 \\
\hline 49 & WP_000587664.1 & & VOC family protein & 198.7 & 35.6 & 428.8 & 2.3 \\
\hline 50 & WP_000658301.1 & & $\begin{array}{c}\text { DNA } \\
\text { starvation/stationary } \\
\text { phase protection protein }\end{array}$ & 33.3 & 54.1 & 22.1 & 2.3 \\
\hline 51 & WP_000278813.1 & & $\begin{array}{l}\text { DUF192 } \\
\text { domain-containing } \\
\text { protein }\end{array}$ & 2.0 & 2.9 & 1.2 & 2.1 \\
\hline 52 & WP_001221057.1 & LIC_10711 & hypothetical protein & 5.1 & 8.7 & - & 1.7 \\
\hline 53 & WP_001007329.1 & LIC_12437 & hypothetical protein & 94.4 & 8.0 & 151.1 & 1.7 \\
\hline 54 & WP_000464920.1 & & $\begin{array}{l}\text { stage II sporulation } \\
\text { protein E }\end{array}$ & 2.6 & - & 4.1 & 1.6 \\
\hline 55 & WP_000478308.1 & & $\begin{array}{c}\text { sphingomyelin } \\
\text { phosphodiesterase }\end{array}$ & 1.8 & 0.7 & 2.1 & 1.6 \\
\hline 56 & WP_000240010.1 & LIC_11555 & $\begin{array}{l}30 \text { S ribosomal protein } \\
\text { S16 }\end{array}$ & 27.9 & - & 42.3 & 1.5 \\
\hline
\end{tabular}




\subsection{Bioinformatics Analysis of Secretory Proteins}

\subsubsection{Prediction of Subcellular Location of Extracellular Proteins Identified in Leptospira}

Our results showed that CELLO v.2.5 predicted that $21.4 \%$ of the extracellular proteins would be same, while PSORTb predicted $12.5 \%$ and BUSCA predicted $8.9 \%$ to be extracellular (Figure 2). Most of the predictions made by CELLO v.2.5 involved cytoplasmic (41\%) and Outer Membrane Protein (OMP) proportions (26.8\%) In the case of PSORTb, the predictions were that it was cytoplasmic $(26.8 \%)$ and unknown $(35.7 \%)$ while the BUSCA predicted that cytoplasmic $(53.6 \%)$ and inner membrane proteins $(35.7 \%)$ would be a major portion of Leptospira (Table 1).
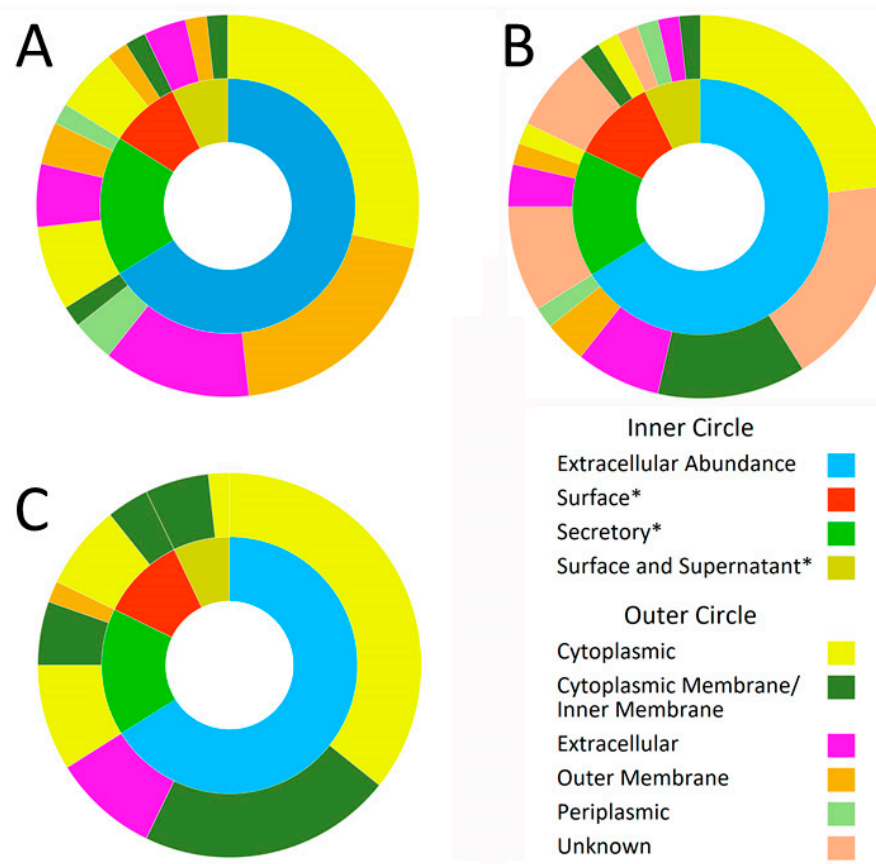

Figure 2. Prediction of extracellular proteins. Distribution of a number of extracellular proteins identified in the abundance-based groups of wash and supernatant of Leptospira culture in EMJH medium (the inner circle) into the bioinformatically predicted locations of the proteins (outer circle). The ${ }^{* \prime}$ represents proteins identified exclusively from the indicated fraction. Part (A) shows the distribution of CELLO v.2.5 predicted subcellular locations, (B) shows PSORTb predicted subcellular locations, and (C) BUSCA predicted subcellular locations of extracellular proteins identified from wash and supernatant (Supplementary Table S1).

\subsubsection{Prediction of Protein Function and Pathogenic Nature}

Identification of the role of the proteins identified as extracellular is important to assess their usefulness in an anti-leptospirosis strategy. The KEGG database showed seven classes of functional groups in the 56 proteins (Figure 3A). Four proteins were found under a metabolism that includes the Amino acid metabolism (1), Carbohydrate metabolism (1), Energy metabolism (1), and Metabolism of cofactors and vitamins (1). In the Cellular Processes under the Cellular community-prokaryotes, in the Genetic Information Processing under folding, sorting and degradation, and in Environmental Information Processing under Membrane transport one protein each category. The BRITE hierarchy showed 8 proteins which are distributed under the Protein families; genetic information processing 3, metabolism 3, signaling and cellular processes 2 proteins were present. Under Genetic Information Processing, two Replication and repair proteins and one Translation activity were present. There was one Unclassified signaling and cellular processes protein that is not included in any pathway or BRITE. 

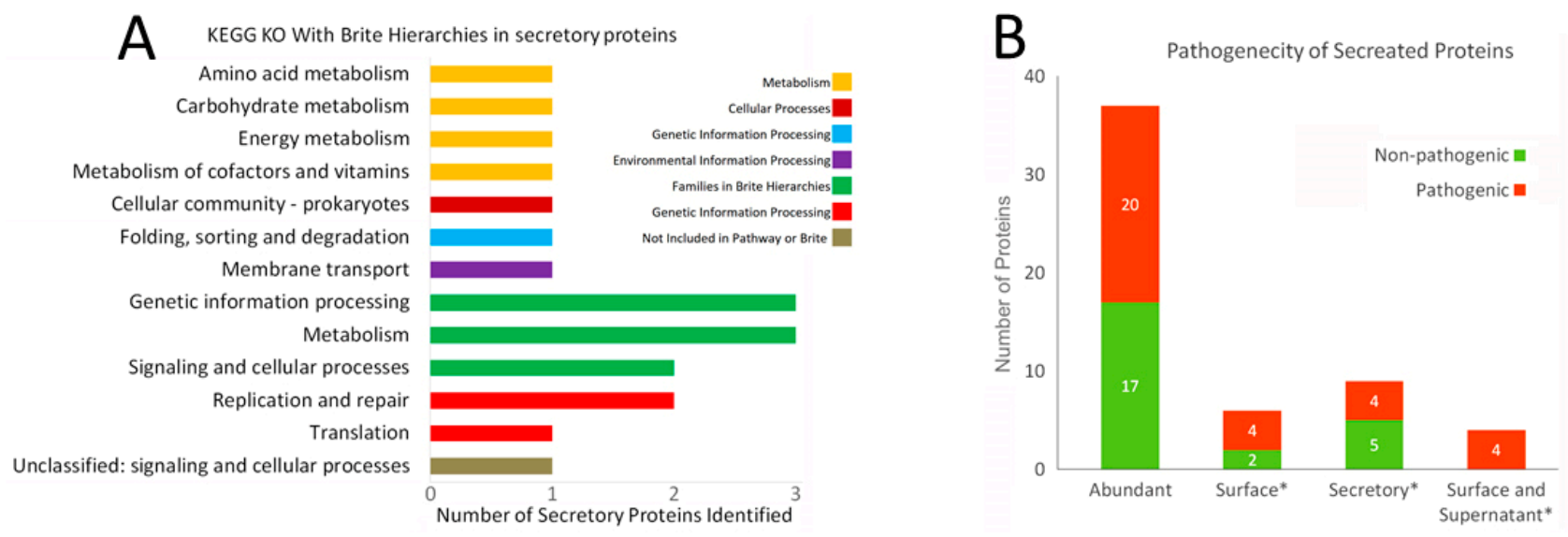

Figure 3. Functional characteristics of extracellular proteins. The bar graph (A) shows the functional annotation of 56 extracellular proteins based on the KEGG database that shows seven families of proteins and the number of class proteins in each family. The details are shown in the Supplementary Table S2. Part (B) shows pathogenic/virulent proteins identified using MP3 online server represented as abundance-based groups where 'Abundant' proteins are those proteins found to be extracellular due to indicating a $>1.5$ times higher amount present in the wash (surface) and supernatant (secretory). * indicates proteins that were exclusively found on the surface and/or as secretory and were not found in any cellular fractions.

The severity of an infection caused by a pathogen is determined by the virulent and pathogenic proteins present in an organism. The MP3 online server predicted that out of 56 proteins, 32 were pathogenic/virulent and 24 were nonpathogenic (Figure 3B). The abundant 37 proteins that were found to be cellular included 20 pathogenic proteins and 17 nonpathogenic proteins. Out of the 19 exclusive proteins found in wash and supernatant, 12 were pathogenic and seven were nonpathogenic. There were eight pathogenic proteins out of 10 exclusive proteins found in the wash.

These results showed that the proteins determined to be secretory may provide a balance between the pathogenic and non-pathogenic proteins which progressively determine the Leptospira based on the environmental conditions.

\subsubsection{Identification of Orthologous Proteins}

The NCBI protein-protein BLAST (blastp) retrieved orthologous proteins of 56 secretory proteins. The 'query cover' and 'identity' values were used to analyze protein similarity with the query sequence, which was the secretory protein of L. interrogans. The Leptospira species represented in the BLAST result were arranged according to the P1, P2, S1, and S2 groups, and the same sequence was shown of a phylogenetic tree constructed with the ppk gene sequences in Figure 4 as from an earlier study that describes 64 species of Leptospira [23]. The result showed the highest coverage and identity of 26 extracellular proteins with 17 species of pathogenic Leptospira (Figure 4). The intermediate, as well as saprophytic species, showed less than 50\% identity though having good coverage against the query sequences. 


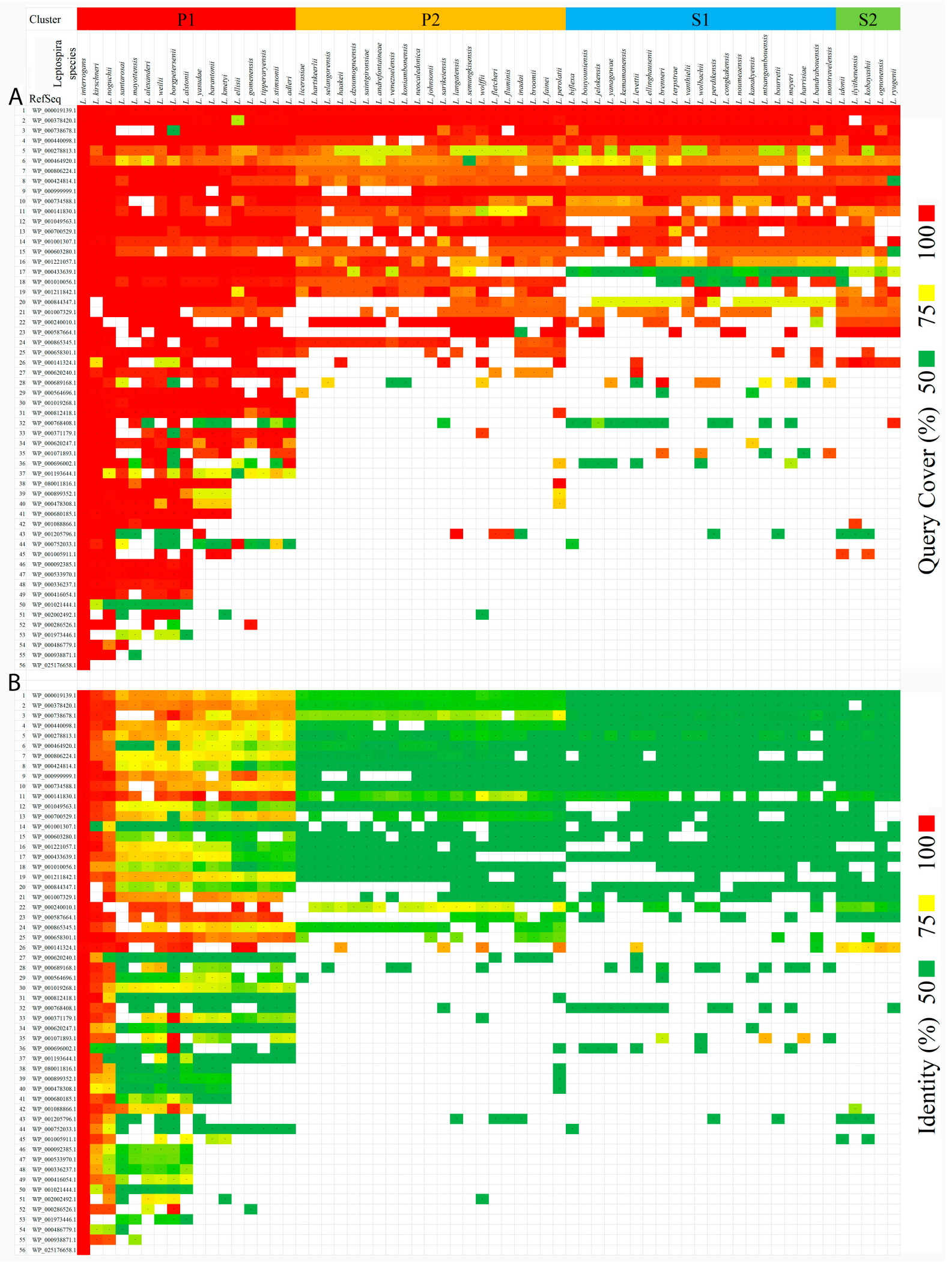

Figure 4. Analysis of orthologous proteins from 64 Leptospira species. The figure shows 'query cover' (A) and 'identity' (B) of orthologous proteins found in 64 species of Leptospira in an NCBI-BLAST search against 56 extracellular proteins of L. interrogans. The proteins represented as RefSeq were arranged in the highest to the lowest order of the sum of query cover and identity values that each protein scored from those Leptospira species it was identified as being part of. The Leptospira species were arranged based on their phylogenetic hierarchy and based on ppk gene sequences. 


\subsubsection{Determination of Protein Interactions}

As a representative study, four proteins: Histidine kinase sensor protein (LIC_11528), DNA helicase (LIC_11624), Putative lipoprotein containing peptidase M75 domain (LIC_10713), and Peptidase C39 domain protein (LIC_10511) showed an abundance of 1771-, 125-, 79-, and 76-times, respectively, in extracellular samples that were subjected to string analysis to find inter-correlation among the various proteins within the Leptospira group (Figure 5). The C39 peptidase group was found to be associated with LIC 10510 and LIC 10512 where no functional analysis was interpreted. Also, putative lipoprotein (Imelysin domain) was predicted to associate with gene encoding proteins i.e., LIC 10712, LIC 11466, and LIC 10711, thereby resembling a neighborhood and co-occurrence among the species. Further, histidine kinase sensory proteins were found to be associated with other chemotaxis response regulator proteins. This association was also determined by neighborhood relationships within the species. Further, DNA helicase was found to be involved with uvrB, mutL, recQ, recA, pheT, polA, and lig proteins. These associations were determined experimentally with DNA helicase.

A

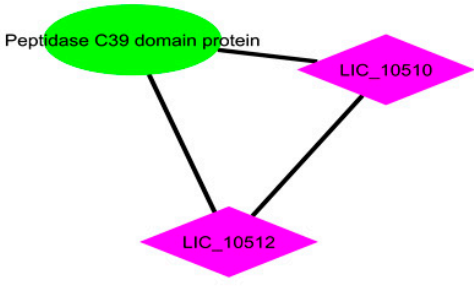

C

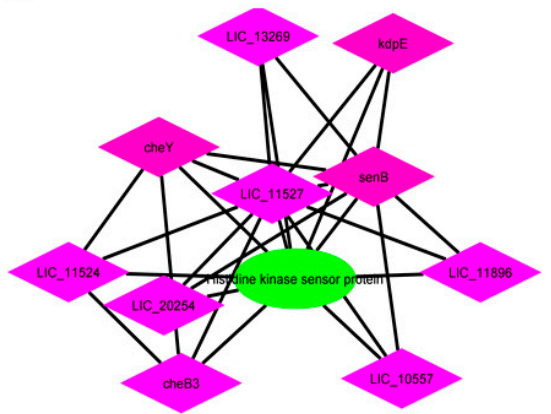

B

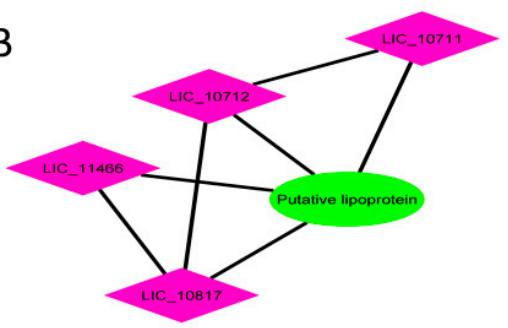

D

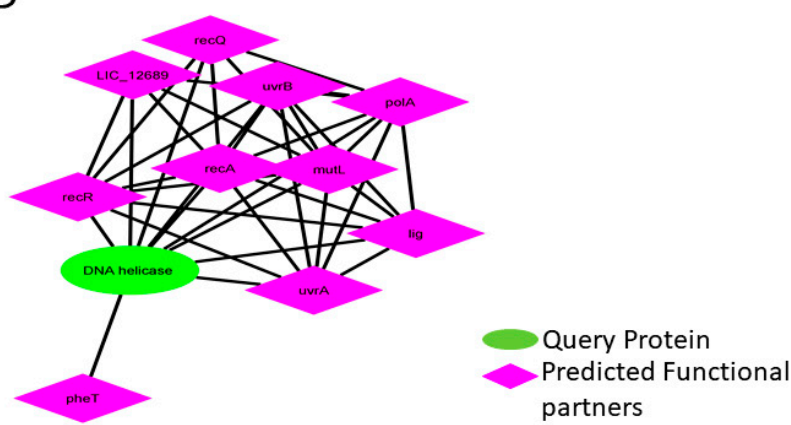

Figure 5. STRING based analysis of extracellular proteins. Each group of interactome depicts the interaction among the proteins within the Leptospira group: (A) Peptidase_C39 domain protein; (B) Putative lipoprotein; (C) Histidine kinase sensor protein; (D) DNA helicase.

\section{Discussion}

Bacteria secrete a wide variety of proteins, enabling them to respond to their environment. These extracellular proteins have a diverse functional role such as degradation of substrates, response to environmental stimulus, migration, genetic exchange, feeding, ion-capturing, and sociobiological aspects like quorum sensing, biofilm formation, and host-pathogen interaction [24,25]. In this context, identification and characterization of extracellular proteins of Leptospira help in elucidating the functions of proteins that lead to pathogenesis and survival of the pathogen in the host. This study was conducted with the same sample that describes cellular proteins. Identification of proteins that are exclusively present in extracellular samples like wash and supernatant in spite of high-resolution analysis cellular fractions, which were separately analyzed in three (aqueous, detergent, and pellet) fractions, underlines the quality of extracellular protein preparations. Similarly, the exclusive proteins found within wash and supernatant samples showed the discriminatory power of the preparations to distinguish between surface and secretory groups in 
extracellular proteins. Out of 1176 unique proteins identified from wash and supernatant samples, 56 proteins were found with $>1.5$-fold abundance that indicates that $4.76 \%$ were extracellular proteins. The 19 abundant proteins found exclusively in the extracellular group showed a $1.61 \%$ rate of proteins identified in the wash and supernatant. The surface proteins were extracted in PBS containing $5 \mathrm{mM} \mathrm{MgCl} 2$ that was easily detachable and also had the unique presence of six proteins without shedding out into the supernatant, which showed its sufficiently good binding on the surface of Leptospira. It is also worth noting that $57 \%$ of the extracellular proteins found were pathogenic in nature, as was predicted by MP3 tool with a $27.9 \%$ rate ( 826 pathogenic proteins out of the 2957 proteins identified) in the whole proteome of Leptospira [22]. Even though some of these proteins were found in lower quantities, the possibility of upregulation of the proteins under pathogenic conditions cannot be ignored. This underlines the significance of identification of these extracellular proteins.

The bioinformatics prediction of extracellular proteins using online tools did not achieve any appreciable level, as the true prediction with respect to 56 extracellular proteins made by CELLO v.2.5, PSORTb, and BUSCA were $21.4 \%, 12.5 \%$, and $8.9 \%$, respectively. Similarly, five proteins of the extra-cellular proteins were identified as extracellular proteins predicted in a previous report [25]. This shows the need for further improvements in the algorithms to predict extracellular proteins of Leptospira.

Though the species was arranged against a preexisting phylogenetic hierarchy, based on ppk gene sequences, the data matched with the clusters and sequence of species. This shows that the extracellular proteins can discriminate between Leptospira species and the unique extracellular proteins may have key functions in invasion, pathogenesis, or survival of the organism in the host. These can be used for diagnostic applications and identification of Leptospira species. The orthologous proteins in other species of Leptospira showed that all the 17 pathogenic proteins were closely related to the L. interrogans with respect to the 26 proteins with $>90 \%$ coverage and $>75 \%$ identity among the species. Three proteins: the WP_000141830.1 a Multispecies preprotein translocase subunit YajC, the WP_000587664.1 as a VOC family protein, and the WP_000658301.1 as a DNA starvation/stationary phase protection protein were found to be more closely related within the pathogenic forms. With respect to the preprotein translocase subunit YajC, it was reported that mice vaccinated with the yajC of Brucella abortus showed immune responses to YajC [26].

With an abundance of 1700-times in wash with respect to cellular and supernatant fraction, histidine kinase sensor protein (LIC_11528) was identified as the most abundant and pathogenic protein identified on the surface of Leptospira in this study. The gene ontology was predicted to carry functions like signal transduction, and phosphorylation and molecular functions like phosphorylase sensor kinase activity and transferase activity by transferring phosphorus-containing groups. This shows that the protein is a two-component system with a histidine protein kinase (HPKs) and a response regulator protein [27]. The phosphorylation can induce conformational changes in the regulatory domain, resulting in the activation of the associated domain that affects the response. This shows that bacterial two-component pathways can control a dazzling array of functions like cell division, virulence, antibiotic resistance, response to environmental stress, sporulation, metabolite fixation and utilization, and taxis [28]. In addition, HPKs are unique signal transducers that are not common in animals, indicating this molecule can be a good target for an anti-leptospiral strategy [29]. Further, the STRING analysis identified the interaction of this domain with a cheY protein resembling the bacterial adaptions to the environment through the activation of specific sensory receptors along with signal processing proteins [30]. Apart from these properties, LIC_11528 is an ortholog of LA_2421 of L. interrogans serogroup Icterohaemorrhagiae serovar Lai and was found to be associated with the chemotaxis and signal transduction system [31]. Chemotaxis is one of the important mechanisms that drive a pathogen towards its target organs [32].

The second abundant protein was DNA helicase (LIC_11624,) which was found to be 38 -fold greater on the surface and 87 -fold greater in the supernatant than its entire quantity 
in the cell. This was found to be nonpathogenic in MP3 and the gene ontology showed molecular functions like DNA helicase activity, ATP binding, DNA binding, and hydrolase activity. The STRING analysis showed the association with uvr A and uvr B types of DNA repair gene homologs, which are involved in repairing of DNA that is damaged due to stress factors such as ultraviolet light $[33,34]$. DNA helicase is also associated with proteins like the DNA mismatch repair protein MutL, which determines the mismatched provoked excision step [35] and the RecQ helicase, which are widely conserved in bacteria [36] and helps in unwinding complementary strands of DNA required for the proper repair of DNA damage. However, the function of this DNA helicase as an extracellular entity is not yet known.

The putative lipoprotein containing peptidase M75 domain (LIC_10713) was found to be 78-times more abundant in the supernatant as a secretory molecule. The protein contains an Imelysin-like domain with a GxHxxE signature. This domain was distributed widely in bacteria and was found to be involved in iron transport [37]. This protein showed 100\% Query Cover and 97.73\% identity LruB, which was found to be playing a significant role in human and equine recurrent uveitis as well as antibodies against the protein are identified in patients diagnosed with Fuchs uveitis [38-40]. It is also found that the in vitro growth of Leptospira was significantly reduced when LruB is inactivated [41].

The gene LIC_10511 encoding the protein C39 peptidase, which has been found to be 75-fold abundant in the supernatant, was reported to be an endo-peptidase family that mostly serves as ABC transporters along with the translocation of the mature bacteriocin across the cytoplasmic membrane [42]. This protein was also abundantly present in the supernatant resembling type III secreted effectors (T3SEs), type IV secretion (T4SS), and a type VI secretion system [43-45]. The Type VI secretion system was widely reported in $E$. coli, which was found to be directly associated to pathogenesis leading to macrophage survival, which can further lead to events of lateral gene transfer [46,47]. This interconnected mechanism allows the bacteria to participate in metal uptake and provide an advantage during bacteria-bacteria competition. Further, it also allows the bacteria to widely deliver the effector toxic proteins directly into neighboring cells [48].

Apart from these four proteins, other proteins also showed a significant rise in quantity as secretory molecules as compared to their presence in aqueous, detergent, and pellet fractions. These proteins were found to carry functions like cell-cell signaling, determining nutritional requirement, stress response, external specific stimuli, and homeostasis, which were interpreted by InterProScan 5. Further, significant domain class proteins like chaperone proteins, VOC family, SGNH hydrolase, ComF, and ATP binding cassette proteins were also identified from our study. Previous studies reported the presence of these domains in Leptospira determining the functions like survival under stress conditions, cell-cell signaling, and binding to membrane receptors [49-51].

\section{Materials and Methods}

\subsection{Study Design}

The Leptospira culture in complete EMJH medium at standard culture condition was used for a complete subcellular proteomic analysis using Triton X-114, as shown in Figure 6. The study comprised of two parts: (1) subcellular proteome which includes all the fractions of Triton X-114 fractionation considered as cellular proteins; and (2) the extracellular proteins obtained from a wash of the Leptospira pellet (surface) and proteins enriched from the culture supernatant (secreted). The total amount of each protein from Triton X-114 fractions identified in part one was added together and considered as a cellular portion of the protein in contrast to the number of the same extracellular proteins found, which is part two. 


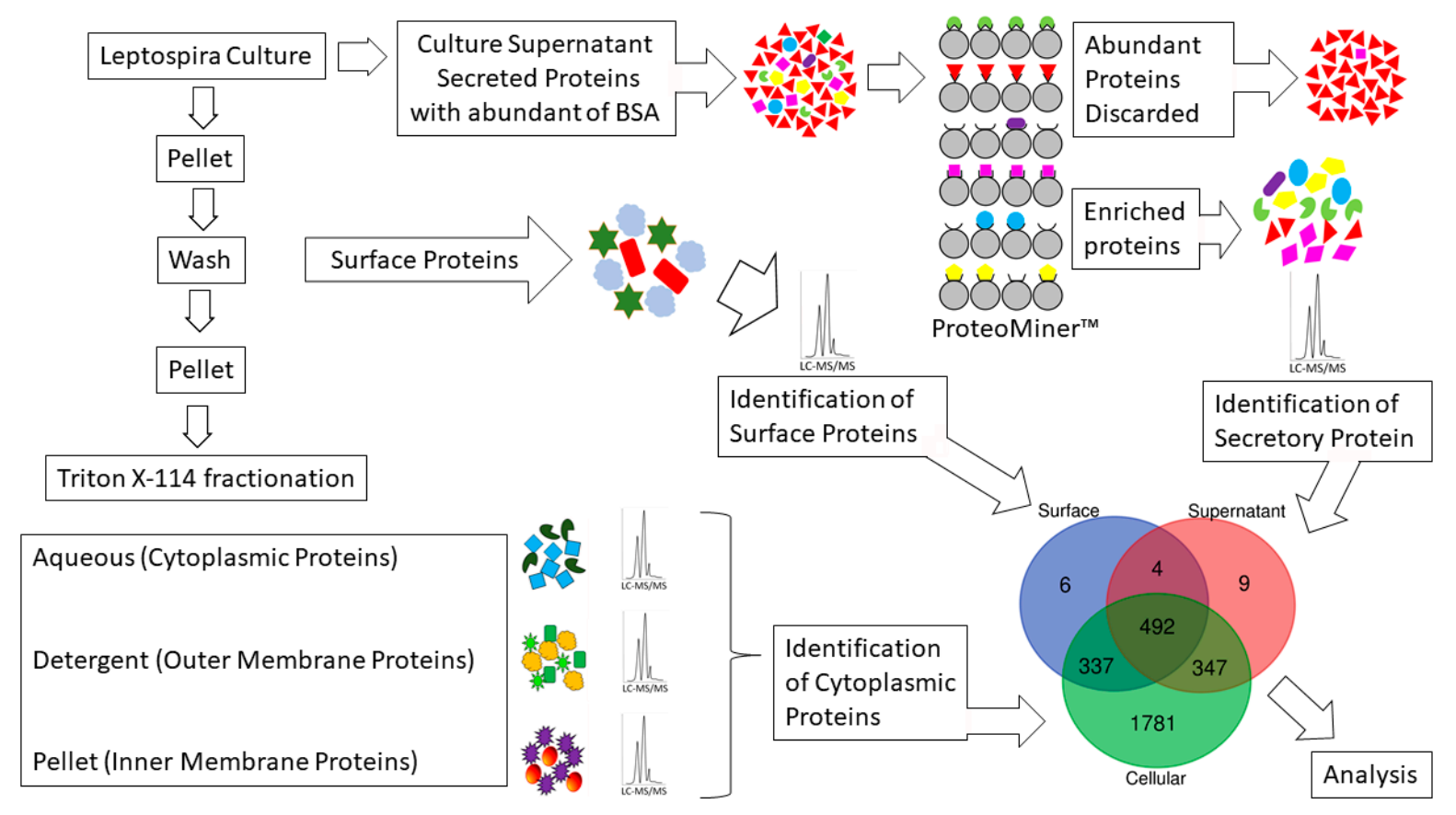

Figure 6. Proteomics workflow to identify extracellular proteins. The study design shows Triton X-114 fractionation of cellular proteins, extraction of surface proteins, and ProteoMiner ${ }^{\mathrm{TM}}$ (Bio-Rad) based enrichment of secreted proteins from Leptospira culture supernatant for LC-MS/MS analysis.

\subsection{Leptospira Strain and Culture}

L. interrogans Copenhageni stain Fiocruz L1-130 was obtained from the repository of the ICMR-Regional Medical Research Centre, Port Blair, India. This is a WHO Collaborating Center for diagnosis, reference, research, and training in leptospirosis. Leptospira were cultured in EMJH medium supplemented with $1 \%$ bovine serum albumin at $30^{\circ} \mathrm{C}$ with intermittent checking for contamination and growth. Afterwards, they were harvested at the mid-log phase for further protein extraction.

\subsection{Enrichment of Surface and Extracellular/Secreted Protein}

The mid-log phase culture of Leptospira was centrifuged at $2500 \times \mathrm{g}$ for $30 \mathrm{~min}$ at $4{ }^{\circ} \mathrm{C}$ to obtain the culture supernatant for the separation of secretory protein. This supernatant was further centrifuged at $6000 \times g$ for $30 \mathrm{~min}$ to remove any Leptospira left in the medium and the supernatant was again centrifuged at $12,000 \times g$ for $30 \mathrm{~min}$. The three-step centrifugation was to avoid tight packing and rupture of Leptospira while pelleting. This supernatant was used to separate secretory/extracellular proteins.

\subsection{Extraction of Extracellular/Secreted Proteins}

The secretory proteins present in low abundance in comparison with the BSA or serum proteins. Enrichment of secretory proteins was carried out using ProteoMiner ${ }^{\mathrm{TM}}$ Bio-Rad (Hercules, CA, USA) protein enrichment technology based on binding of proteins to a library of combinatorial peptide ligands that act as unique binders for proteins [52,53].

The supernatant was dialyzed against PBS (containing $150 \mathrm{mM} \mathrm{NaCl}, \mathrm{pH}$ 7.4) to facilitate optimum binding condition to ProteoMiner ${ }^{\mathrm{TM}}$. Slurry from ProteoMiner ${ }^{\mathrm{TM}}$ LargeCapacity column (100 $\mu \mathrm{L}$ settled beads) was washed two times with $1 \mathrm{~mL}$ of PBS and added to $100 \mathrm{~mL}$ of the supernatant and allowed to bind overnight $(>8 \mathrm{~h})$ under shaking at $4{ }^{\circ} \mathrm{C}$. After binding, the beads were allowed to settle and we removed the clear volume of supernatant, repacked in the ProteoMiner ${ }^{\mathrm{TM}}$ column, and carried out $2 \times 100 \mu \mathrm{L}$ washes with PBS. The elution $2 \times 20 \mu \mathrm{L}$ was made using Elution Reagent (8 M urea, 2\% CHAPS) supplied by the manufacturer. The eluted secretory protein was subjected to quantification, 
electrophoretic characterization, and trypsin digestion to obtain peptides and further high-resolution LC-MS/MS based proteomics.

\subsection{Extraction of Surface Proteins}

The pellet obtained after separation of supernatant was washed $3 \times$ with PBS containing $5 \mathrm{mM} \mathrm{MgCl} 2$ and we collected the wash supernatant by centrifuging the leptospires at $2500 \times g$ for $5 \mathrm{~min}$ at room temperature. The wash was again centrifuged at $12,000 \times g$ for $30 \mathrm{~min}$ to remove any trapped leptospires and the supernatant was designated as a 'Wash fraction' that contains washable surface proteins of Leptospira and used for further processing to carry out LC-MS/MS.

\subsection{Triton X-114 Extraction}

The Leptospira pellet obtained after wash was used for Triton X-114 fractionation as described earlier [22]. The extraction buffer containing $10 \mathrm{mM}$ Tris ( $\mathrm{pH} 8)$ carrying $1 \%$ Triton X-114 and $150 \mathrm{mM} \mathrm{NaCl}$ at $4{ }^{\circ} \mathrm{C}$ at the rate of $1 \mathrm{~mL}$ of extraction buffer per amount of pellet derived from a $25 \mathrm{~mL}$ mid-log phase culture was used for extraction. The extract was centrifuged at $12,000 \times \mathrm{g}$ for $30 \mathrm{~min}$ at $4{ }^{\circ} \mathrm{C}$ and the pellet was saved as a 'pellet fraction' and the supernatant was used for phase separation. The Triton X-114 concentration of the supernatant was increased to $2 \%$ by the addition of an adequate amount of Triton $\mathrm{x}-114$, depending on the volume, mixed well, and incubated at $37^{\circ} \mathrm{C}$ for $1 \mathrm{~h}$ for phase separation, then it was subsequently centrifuged at $1500 \times g$ for $5 \mathrm{~min}$ to separate the upper aqueous phase from the lower detergent phase. The undissolved proteins from the pellet from the TritonX-114 extraction step, which contained a cytoplasmic cylinder, were further extracted using a buffer containing $10 \mathrm{mM}$ Tris- $\mathrm{Cl}$ (pH8), $8 \mathrm{M}$ urea, $4 \mathrm{mM}$ dithiothreitol, and $1 \%$ sodium dodecyl sulfate. Following centrifugation at $12,000 \times \mathrm{g}$ for $30 \mathrm{~min}$ at $4{ }^{\circ} \mathrm{C}$, the supernatant was used as the pellet fraction. Similar fractions of all four replicated were polled and the protein concentrations were estimated using the BCA method in the aqueous, detergent, and pellet fractions, which were then stored at $-20^{\circ} \mathrm{C}$. This protein was used for mass spectrometry. Data from three replications of the same kind was used for further analysis.

\subsection{Mass Spectrometry Analysis \\ 4.7.1. In-Solution Digestion}

Wash and supernatant samples protein concentrations were estimated by using the BCA (Bicinchoninic Acid) Protein Assay (Pierce ${ }^{\mathrm{TM}}$ BCA Protein Assay Kit), and the protein amount was reconfirmed visually resolving on a 10\% SDS-polyacrylamide gel electrophoresis (PAGE) gel. Based on the protein concentrations, a quantity equivalent to $250 \mathrm{~g}$ of protein was taken from wash and supernatant samples. Further samples were reduced with $10 \mathrm{mM}$ dithiothreitol (DTT) and alkylated with $20 \mathrm{mM}$ iodoacetamide (IAA). Prior to trypsin digestion, the lysate was precipitated with acetone to remove sodium dodecyl sulfate (SDS) to form the protein sample. The protein was digested with trypsin (1:20) (modified sequencing grade; Promega, Madison, WI, USA) at $37^{\circ} \mathrm{C}$ for $16 \mathrm{~h}$. The peptides were dried overnight in SpeedVac and stored at $-20^{\circ} \mathrm{C}$.

\subsubsection{Basic pH RPLC Based Fractionation}

Lyophilized peptides were subjected to basic $\mathrm{pH}$ reverse phase chromatography (bRPLC) fractionation. The samples were reconstituted in $1 \mathrm{~mL}$ of $10 \mathrm{mM}$ Triethylammonium bicarbonate (TEABC) and separated on an XBridge C18 column (Waters Corporation, Milford, MA, USA; 130, $5 \mathrm{~m}, 250 \times 4.6 \mathrm{~mm}$ ) attached to a Hitachi LaChrom Elite HPLC system over 120 min using a linear gradient increase from $5 \%$ to $100 \%$ of $10 \mathrm{mM}$ TEABC with $90 \%$ acetonitrile. Initially, 96 fractions were collected, which were then concatenated to 6 fractions and dried before desalting with $\mathrm{C} 18$ cartridges. Desalted peptides were vacuum dried and stored in a deep freezer at $-80^{\circ} \mathrm{C}$ prior to LC-MS/MS analysis. 


\subsubsection{LC-MS/MS Analysis}

The tryptic peptides from bRPLC fractionation were analyzed on a Thermo Fischer Scientific Orbitrap Fusion Tribrid mass spectrometer (Thermo Fischer Scientific, Bremen, Germany) connected with an Easy-nLC-1200 nanoflow liquid chromatography system (Thermo Fischer Scientific). The lyophilized peptides were reconstituted in $0.1 \%$ formic acid and loaded onto a $2 \mathrm{~cm}$ trap column (nanoViper, $3 \mu \mathrm{m} \mathrm{C18} \mathrm{Aq)} \mathrm{(Thermo} \mathrm{Fisher}$ Scientific). Peptides were separated using a $15 \mathrm{~cm}$ analytical column (nanoViper, $75 \mu \mathrm{m}$ silica capillary, $2 \mu \mathrm{m} \mathrm{C18} \mathrm{Aq)} \mathrm{at} \mathrm{a} \mathrm{flow} \mathrm{rate} \mathrm{of} 300 \mathrm{nl} / \mathrm{min}$. For data-dependent acquisition, solvent gradients were set as the linear gradient of $5-35 \%$ solvent B $(80 \%$ acetonitrile in $0.1 \%$ formic acid) over $90 \mathrm{~min}$ through 120 -min run time. MS analysis was carried out at a scan range of $400-1600 \mathrm{~m} / \mathrm{z}$ mass range $(120,000$ mass resolutions at $200 \mathrm{~m} / \mathrm{z})$. The maximum injection time was $10 \mathrm{~ms}$. For MS/MS analysis, data were acquired at top speed mode with $3 \mathrm{~s}$ cycles and subjected to a higher collision energy dissociation with $32 \%$ normalized collision energy. MS/MS scans were carried out at a range of 100-1600 m/z using Orbitrap mass analyzer at a resolution of 30,000 at $200 \mathrm{~m} / \mathrm{z}$. The maximum injection time was $200 \mathrm{~ms}$.

\subsubsection{MS/MS Data Analysis}

Mass spectrometry-derived data were searched against the L. interrogans serogroup Icterohaemorrhagiae serovar Copenhageni (strain Fiocruz L1-130) reference protein database obtained from NCBI (3667 protein entries), with common contaminants added to the protein database (115 contaminants entries). The mass spectrometry data was analyzed with Mascot (versions 2.5.1; Matrix Science, London, UK) and SEQUEST-HT search algorithms in the Proteome Discoverer software suite, version 2.2 (PD 2.2) (Thermo Fischer Scientific, Bremen, Germany). The search parameters used were: (a) trypsin as the proteolytic enzyme (with up to one missed cleavage); (b) fragment mass error tolerance of $0.05 \mathrm{Da}$; (c) peptide mass error tolerance of $10 \mathrm{ppm}$; (d) oxidation of methionine as a variable modification; (e) carbamidomethylation of cysteine as a fixed modification. A false discovery rate (FDR) was set to $1 \%$ at PSM and peptide levels. The iBAQ (Intensity Based Absolute Quantification) value was generated using the $\mathrm{iBAQ}$ algorithm that estimates the relative abundance of the proteins within each sample [54].

\subsubsection{Data Availability}

The proteomics data of these mass spectrometry analyses have been deposited to the ProteomeXchange Consortium via the PRIDE [55], the partner repository with the dataset identifier.

\subsubsection{Bioinformatics Analysis \\ Sub-Cellular Localization}

To predict the sub-cellular location of secreted proteins, online tools like CELLO v.2.5 [56,57] (cello.life.nctu.edu.tw/, accessed on 5 March 2020) and PSORTb version 3.0.2 [58] tool (https://www.psort.org/psortb/, accessed on 9 March 2020) were used. Additionally, a web-server BUSCA (Bologna Unified Subcellular Component Annotator, http:/ / busca.biocomp.unibo.it/, accessed on 19 April 2021) which integrates different tools (DeepSig, TPpred3, PredGPI, BetAware, and ENSEMBLE3.0) to predict localization-related protein features as well as tools like BaCelLo, MemLoci, and SChloro for discriminating subcellular localization of both globular and membrane proteins while predicting subcellular localization [59].

\section{Prediction of Protein Function and Pathogenic Nature}

Functional annotation of the secretory protein is important to know the role of these proteins. Identification of functions and metabolic pathways of these proteins were made using the KEGG database (https:/ / www.genome.jp/kegg-bin/show_brite?lic, accessed on 28 February 2021) [60]. Similarly, virulence and pathogenicity are key determinants of 
the severity of infection caused by a pathogen. To identify virulent proteins, we used MP3 (http:/ / metagenomics.iiserb.ac.in/mp3/application.php, accessed on 12 April 2020) [61]. This tool is an SVM-based method to characterize the pathogenic proteins from the nonpathogenic ones.

\section{Identification of Orthologous Proteins}

A search for orthologous proteins of extracellular within 64 species of Leptospira was carried out using algorithm blastp (protein-protein BLAST) under online NCBI BLAST search at default parameters to retrieve top 1000 hits. Orthologous proteins of the highest score from each Leptospira species, irrespective of strains, were selected along with their 'query cover' and 'identity' values with respect to the query sequence.

Analysis of Interacting Proteins

To predict the protein-protein interaction among the species of Leptospira, we used String database (http:/ / version10.string-db.org/, accessed on 21 May 2021) version 10. Under the search option, we entered the unique protein uniport ID and selected the autodetect option [62].

\section{Conclusions}

This study aimed to identify extracellular proteins of L. interrogans from protein-rich EMJH medium. It shows that the surface and secretory proteins can be easily identified with reference to the cellular proteins in quantitative terms. The extraction method was found to be easy, rational, and justified with the identification of exclusive molecules and significant times of abundance with respect to the cellular fraction of the proteins, though it was analyzed at higher resolutions due to three Triton X-114 fractions. Identification of pathogenic proteins and the correlation with pathogenic species shows the significance of the identified proteins. Similarly, a huge number (57\%) of pathogenic proteins present as secretory molecules also highlight the significance of extracellular proteins. These key molecules identified can implement various functions like nutrient acquisition, cell-cell communication, detoxification of environment, and attaching to potential inhibitors. In this regard, the article presents an efficient method for extraction and analysis of extracellular proteins for other organisms too, as well as identification of extracellular proteome of L. interrogans.

Supplementary Materials: The following are available online at https:/ /www.mdpi.com/article/10 .3390/pathogens10070852/s1, Table S1: List of proteins identified in LC-MS/MS, Table S2: KEGG based search for function of extracellular proteins.

Author Contributions: Conceptualization, M.G.M. and D.G.; methodology, M.G.M. and T.S.; software, A.S. and H.P.; validation, A.S., H.P. and H.P.; formal analysis, M.G.M. and A.S.; investigation, A.S. and T.S.; resources, D.A.B.R., K.M.K. and S.M.P.; data curation, D.A.B.R.; writing-original draft preparation, A.S.; writing-review and editing, M.G.M. and D.G.; visualization, A.S.; supervision, M.G.M.; project administration, M.G.M. and T.S.K.P.; funding acquisition, M.G.M. and T.S.K.P. All authors have read and agreed to the published version of the manuscript.

Funding: This research was partly funded by Indian Council of Medical Research, New Delhi, India, Grant No. Leptos/22/2013-ECD-I and Department of Science and Technology, Science and Engineering Research Board, New Delhi, India, Grant No. SR/SO/HS/0108/2012.

Institutional Review Board Statement: Ethical review and approval was not applicable for this study as not involving humans or animals.

Informed Consent Statement: Informed Consent was not applicable for this study as not involving humans or animals.

Data Availability Statement: The LC-MS/MS proteomics dataset is available through ProteomeXchange dataset identifiers PXD009050, PXD016204 and PXD026044.

Conflicts of Interest: The authors declare no conflict of interest. 


\section{References}

1. Karpagam, K.B.; Ganesh, B. Leptospirosis: A Neglected Tropical Zoonotic Infection of Public Health Importance-An Updated Review. Eur. J. Clin. Microbiol. Infect. Dis. 2020, 39, 835-846. [CrossRef] [PubMed]

2. Samrot, A.V.; Sean, T.C.; Bhavya, K.S.; Sahithya, C.S.; Chandrasekaran, S.; Palanisamy, R.; Robinson, E.R.; Subbiah, S.K.; Mok, P.L. Leptospiral Infection, Pathogenesis and Its Diagnosis-A Review. Pathogens 2021, 10, 145. [CrossRef]

3. Nogueira, S.V.; Backstedt, B.T.; Smith, A.A.; Qin, J.H.; Wunder, E.A.; Ko, A.; Pal, U. Leptospira Interrogans Enolase Is Secreted Extracellularly and Interacts with Plasminogen. PLoS ONE 2013, 8. [CrossRef] [PubMed]

4. Asrat, S.; Davis, K.M.; Isberg, R.R. Modulation of the Host Innate Immune and Inflammatory Response by Translocated Bacterial Proteins. Cell. Microbiol. 2015, 17, 785-795. [CrossRef] [PubMed]

5. Depluverez, S.; Devos, S.; Devreese, B. The Role of Bacterial Secretion Systems in the Virulence of Gram-Negative Airway Pathogens Associated with Cystic Fibrosis. Front. Microbiol. 2016, 7, 1336. [CrossRef]

6. Lebrun, I.; Marques-Porto, R.; Pereira, A.; Pereira, A.; Perpetuo, E. Bacterial Toxins: An Overview on Bacterial Proteases and Their Action as Virulence Factors. Mini-Rev. Med. Chem. 2009, 9, 820-828. [CrossRef]

7. da Silva, L.B.; Menezes, M.C.; Kitano, E.S.; Oliveira, A.K.; Abreu, A.G.; Souza, G.O.; Heinemann, M.B.; Isaac, L.; Fraga, T.R.; Serrano, S.M.T.; et al. Leptospira Interrogans Secreted Proteases Degrade Extracellular Matrix and Plasma Proteins From the Host. Front. Cell. Infect. Microbiol. 2018, 8, 92. [CrossRef]

8. Zuerner, R.L.; Knudtson, W.; Bolin, C.A.; Trueba, G. Characterization of Outer Membrane and Secreted Proteins of Leptospira Interrogans Serovar Pomona. Microb. Pathog. 1991, 10, 311-322. [CrossRef]

9. Wang, H.; Wu, Y.; Ojcius, D.M.; Yang, X.F.; Zhang, C.; Ding, S.; Lin, X.; Yan, J. Leptospiral Hemolysins Induce Proinflammatory Cytokines through Toll-like Receptor 2-and 4-Mediated JNK and NF-kB Signaling Pathways. PLoS ONE 2012. [CrossRef]

10. Bernheimer, A.W.; Bey, R.F. Copurification of Leptospira Interrogans Serovar Pomona Hemolysin and Sphingomyelinase C. Infect. Immun. 1986, 54, 262-264. [CrossRef]

11. Carvalho, E.; Barbosa, A.S.; Gómez, R.M.; Oliveira, M.L.S.; Romero, E.C.; Gonçales, A.P.; Morais, Z.M.; Vasconcellos, S.A.; Ho, P.L. Evaluation of the Expression and Protective Potential of Leptospiral Sphingomyelinases. Curr. Microbiol. 2010, 60, 134-142. [CrossRef] [PubMed]

12. Matsunaga, J.; Medeiros, M.A.; Sanchez, Y.; Werneid, K.F.; Ko, A.I. Osmotic Regulation of Expression of Two Extracellular Matrix-Binding Proteins and a Haemolysin of Leptospira Interrogans: Differential Effects on LigA and Sph2 Extracellular Release. Microbiology 2007. [CrossRef] [PubMed]

13. Biswas, D.; Roy, S.; Vijayachari, P.; Sugunan, A.P.; Natarajaseenivasan, K.; Sehgal, S.C. Comparison of Immunoreactive Proteins of Commonly Circulating Serogroups of Leptospira in Andaman Islands, India. Indian J. Med. Res. 2005, 121, 151-158. [PubMed]

14. Natarajaseenivasan, K.; Vijayachari, P.; Sugunan, A.P.; Sharma, S.; Sehgal, S.C. Leptospiral Proteins Expressed during Acute \& Convalescent Phases of Human Leptospirosis. Indian J. Med. Res. 2004, 120, 151-159.

15. Pietrocola, G.; Nobile, G.; Rindi, S.; Speziale, P. Staphylococcus Aureus Manipulates Innate Immunity through Own and Host-Expressed Proteases. Front. Cell. Infect. Microbiol. 2017, 7, 166. [CrossRef]

16. Galyov, E.E.; Håkansson, S.; Forsberg, Å.; Wolf-Watz, H. A Secreted Protein Kinase of Yersinia Pseudotuberculosis Is an Indispensable Virulence Determinant. Nature 1993, 361, 730-732. [CrossRef]

17. Martinez, E.; Huc-Brandt, S.; Brelle, S.; Allombert, J.; Cantet, F.; Gannoun-Zaki, L.; Burette, M.; Martin, M.; Letourneur, F.; Bonazzi, M.; et al. The Secreted Protein Kinase CstK from Coxiella Burnetii Influences Vacuole Development and Interacts with the GTPase-Activating Host Protein TBC1D5. J. Biol. Chem. 2020, 295, 7391-7403. [CrossRef]

18. Zhang, Y.; Lai, B.S.; Juhas, M.; Zhang, Y. Toxoplasma Gondii Secretory Proteins and Their Role in Invasion and Pathogenesis. Microbiol. Res. 2019, 227, 126293. [CrossRef]

19. Lima, T.S.; Lodoen, M.B. Mechanisms of Human Innate Immune Evasion by Toxoplasma Gondii. Front. Cell. Infect. Microbiol. 2019, 9. [CrossRef]

20. Gomez, S.; Adalid-Peralta, L.; Palafox-Fonseca, H.; Cantu-Robles, V.A.; Soberón, X.; Sciutto, E.; Fragoso, G.; Bobes, R.J.; Laclette, J.P.; Del Pozo Yauner, L.; et al. Genome Analysis of Excretory/secretory Proteins in Taenia Solium Reveals Their Abundance of Antigenic Regions (AAR). Sci. Rep. 2015, 5. [CrossRef]

21. Rana, A.; Thakur, S.; Bhardwaj, N.; Kumar, D.; Akhter, Y. Excavating the Surface-Associated and Secretory Proteome of Mycobacterium Leprae for Identifying Vaccines and Diagnostic Markers Relevant Immunodominant Epitopes. Pathog. Dis. 2016, 74. [CrossRef]

22. Thoduvayil, S.; Dhandapani, G.; Brahma, R.; Devasahayam Arokia Balaya, R.; Mangalaparthi, K.K.; Patel, K.; Kumar, M.; Tennyson, J.; Satheeshkumar, P.K.; Kulkarni, M.J.; et al. Triton X-114 Fractionated Subcellular Proteome of Leptospira Interrogans Shows Selective Enrichment of Pathogenic and Outer Membrane Proteins in the Detergent Fraction. Proteomics 2020, 20, e2000170. [CrossRef] [PubMed]

23. Vincent, A.T.; Schiettekatte, O.; Goarant, C.; Neela, V.K.; Bernet, E.; Thibeaux, R.; Ismail, N.; Mohd Khalid, M.K.N.; Amran, F.; Masuzawa, T.; et al. Revisiting the Taxonomy and Evolution of Pathogenicity of the Genus Leptospira through the Prism of Genomics. PLoS Negl. Trop. Dis. 2019, 13, e0007270. [CrossRef] [PubMed]

24. Passos da Silva, D.; Schofield, M.; Parsek, M.; Tseng, B. An Update on the Sociomicrobiology of Quorum Sensing in Gram-Negative Biofilm Development. Pathogens 2017, 6, 51. [CrossRef] 
25. Viratyosin, W.; Ingsriswang, S.; Pacharawongsakda, E.; Palittapongarnpim, P. Genome-Wide Subcellular Localization of Putative Outer Membrane and Extracellular Proteins in Leptospira Interrogans Serovar Lai Genome Using Bioinformatics Approaches. BMC Genom. 2008. [CrossRef] [PubMed]

26. Vemulapalli, R.; Duncan, A.J.; Boyle, S.M.; Sriranganathan, N.; Toth, T.E.; Schurig, G.G. Cloning and Sequencing of yajC and secDHomologs of Brucella Abortus and Demonstration of Immune Responses to YajC in Mice Vaccinated with B. Abortus RB51. Infect. Immun. 1998, 66, 5684-5691. [CrossRef] [PubMed]

27. Stock, A.M.; Robinson, V.L.; Goudreau, P.N. Two-Component Signal Transduction. Annu. Rev. Biochem. 2000, 69, 183-215. [CrossRef] [PubMed]

28. Falke, J.J.; Bass, R.B.; Butler, S.L.; Chervitz, S.A.; Danielson, M.A. The Two-Component Signaling Pathway of Bacterial Chemotaxis: A Molecular View of Signal Transduction by Receptors, Kinases, and Adaptation Enzymes. Annu. Rev. Cell Dev. Biol. 1997, 13, 457-512. [CrossRef]

29. Wolanin, P.M.; Thomason, P.A.; Stock, J.B. Histidine Protein Kinases: Key Signal Transducers Outside the Animal Kingdom. Genome Biol. 2002, 3. [CrossRef]

30. Welch, M.; Chinardet, N.; Mourey, L.; Birck, C.; Samana, J.P. Structure of the CheY-Binding Domain of Histidine Kinase CheA in Complex with CheY. Nat. Struct. Biol. 1998, 5, 25-29. [CrossRef]

31. Lambert, A.; Wong Ng, J.; Picardeau, M. Gene Inactivation of a Chemotaxis Operon in the Pathogen Leptospira Interrogans. FEMS Microbiol. Lett. 2015, 362, 1-8. [CrossRef]

32. Matilla, M.A.; Krell, T. The Effect of Bacterial Chemotaxis on Host Infection and Pathogenicity. FEMS Microbiol. Rev. 2018, 42, 40-67. [CrossRef]

33. Truglio, J.J.; Croteau, D.L.; Skorvaga, M.; DellaVecchia, M.J.; Theis, K.; Mandavilli, B.S.; Van Houten, B.; Kisker, C. Interactions between UvrA and UvrB: The Role of UvrB's Domain 2 in Nucleotide Excision Repair. EMBO J. 2004, 23, 2498-2509. [CrossRef]

34. Crowley, D.; Boubriak, I.; Berquist, B.; Clark, M.; Richard, E.; Sullivan, L.; DasSarma, S.; McCready, S. The uvrA, uvrB and uvrC Genes Are Required for Repair of Ultraviolet Light Induced DNA Photoproducts in Halobacterium Sp. NRC-1. Saline Syst. 2006, 2,1-13. [CrossRef]

35. Yamaguchi, M.; Dao, V.; Modrich, P. MutS and MutL Activate DNA Helicase II in a Mismatch-Dependent Manner. J. Biol. Chem. 1998, 273, 9197-9201. [CrossRef]

36. Bernstein, K.A.; Gangloff, S.; Rothstein, R. The RecQ DNA Helicases in DNA Repair. Annu. Rev. Genet. 2010, $44,393-417$. [CrossRef] [PubMed]

37. Xu, Q.; Rawlings, N.D.; Farr, C.L.; Chiu, H.-J.; Grant, J.C.; Jaroszewski, L.; Klock, H.E.; Knuth, M.W.; Miller, M.D.; Weekes, D.; et al. Structural and Sequence Analysis of Imelysin-like Proteins Implicated in Bacterial Iron Uptake. PLoS ONE 2011, 6, e21875. [CrossRef] [PubMed]

38. Verma, A.; Rathinam, S.R.; Priya, C.G.; Muthukkaruppan, V.R.; Stevenson, B.; Timoney, J.F. LruA and LruB Antibodies in Sera of Humans with Leptospiral Uveitis. Clin. Vaccine Immunol. 2008, 15, 1019-1023. [CrossRef]

39. Verma, A.; Kumar, P.; Babb, K.; Timoney, J.F.; Stevenson, B. Cross-Reactivity of Antibodies against Leptospiral Recurrent Uveitis-Associated Proteins A and B (LruA and LruB) with Eye Proteins. PLoS Negl. Trop. Dis. 2010, 4, e778. [CrossRef] [PubMed]

40. Verma, A.; Artiushin, S.; Matsunaga, J.; Haake, D.A.; Timoney, J.F. LruA and LruB, Novel Lipoproteins of Pathogenic Leptospira Interrogans Associated with Equine Recurrent Uveitis. Infect. Immun. 2005, 73, 7259-7266. [CrossRef] [PubMed]

41. Eshghi, A.; Pappalardo, E.; Hester, S.; Thomas, B.; Pretre, G.; Picardeau, M. Pathogenic Leptospira Interrogans Exoproteins Are Primarily Involved in Heterotrophic Processes. Infect. Immun. 2015, 83, 3061-3073. [CrossRef]

42. Havarstein, L.S.; Diep, D.B.; Nes, I.F. A Family of Bacteriocin ABC Transporters Carry out Proteolytic Processing of Their Substrates Concomitant with Export. Mol. Microbiol. 1995, 16, 229-240. [CrossRef]

43. Wang, J.; Yang, B.; An, Y.; Marquez-Lago, T.; Leier, A.; Wilksch, J.; Hong, Q.; Zhang, Y.; Hayashida, M.; Akutsu, T.; et al. Systematic Analysis and Prediction of Type IV Secreted Effector Proteins by Machine Learning Approaches. Brief. Bioinform. 2019, 20, 931-951. [CrossRef]

44. Wang, J.; Yang, B.; Leier, A.; Marquez-Lago, T.T.; Hayashida, M.; Rocker, A.; Zhang, Y.; Akutsu, T.; Chou, K.-C.; Strugnell, R.A.; et al. Bastion6: A Bioinformatics Approach for Accurate Prediction of Type VI Secreted Effectors. Bioinformatics 2018, 34, 2546-2555. [CrossRef]

45. Wang, J.; Li, J.; Yang, B.; Xie, R.; Marquez-Lago, T.T.; Leier, A.; Hayashida, M.; Akutsu, T.; Zhang, Y.; Chou, K.-C.; et al. Bastion3: A Two-Layer Ensemble Predictor of Type III Secreted Effectors. Bioinformatics 2019, 35, 2017-2028. [CrossRef] [PubMed]

46. Gallique, M.; Bouteiller, M.; Merieau, A. The Type VI Secretion System: A Dynamic System for Bacterial Communication? Front. Microbiol. 2017, 8, 1-10. [CrossRef] [PubMed]

47. Navarro-Garcia, F.; Ruiz-Perez, F.; Cataldi, Á.; Larzábal, M. Type VI Secretion System in Pathogenic Escherichia Coli: Structure, Role in Virulence, and Acquisition. Front. Microbiol. 2019, 10, 1-17. [CrossRef] [PubMed]

48. Mariano, G.; Trunk, K.; Williams, D.J.; Monlezun, L.; Strahl, H.; Pitt, S.J.; Coulthurst, S.J. A Family of Type VI Secretion System Effector Proteins That Form Ion-Selective Pores. Nat. Commun. 2019, 10. [CrossRef] [PubMed]

49. Diallo, A.; Foster, H.R.; Gromek, K.A.; Perry, T.N.; Dujeancourt, A.; Krasteva, P.V.; Gubellini, F.; Falbel, T.G.; Burton, B.M.; Fronzes, R. Bacterial Transformation: ComFA Is a DNA-Dependent ATPase That Forms Complexes with ComFC and DprA. Mol. Microbiol. 2017, 105, 741-754. [CrossRef] [PubMed] 
50. Knizewski, L.; Steczkiewicz, K.; Kuchta, K.; Wyrwicz, L.; Plewczynski, D.; Kolinski, A.; Rychlewski, L.; Ginalski, K. Uncharacterized DUF1574 Leptospira Proteins Are SGNH Hydrolases. Cell Cycle 2008, 7, 542-544. [CrossRef]

51. Benaroudj, N.; Saul, F.; Bellalou, J.; Miras, I.; Weber, P.; Bondet, V.; Murray, G.L.; Adler, B.; Ristow, P.; Louvel, H.; et al. Structural and Functional Characterization of an Orphan ATP-Binding Cassette ATPase Involved in Manganese Utilization and Tolerance in Leptospira Spp. J. Bacteriol. 2013, 195, 5583-5591. [CrossRef] [PubMed]

52. Thulasiraman, V.; Lin, S.; Gheorghiu, L.; Lathrop, J.; Lomas, L.; Hammond, D.; Boschetti, E. Reduction of the Concentration Difference of Proteins in Biological Liquids Using a Library of Combinatorial Ligands. Electrophoresis 2005, 26, 3561-3571. [CrossRef]

53. Guerrier, L.; Thulasiraman, V.; Castagna, A.; Fortis, F.; Lin, S.; Lomas, L.; Righetti, P.G.; Boschetti, E. Reducing Protein Concentration Range of Biological Samples Using Solid-Phase Ligand Libraries. J. Chromatogr. B 2006, 833, 33-40. [CrossRef]

54. Patil, A.H.; Datta, K.K.; Behera, S.K.; Kasaragod, S.; Pinto, S.M.; Koyangana, S.G.; Mathur, P.P.; Gowda, H.; Pandey, A.; Prasad, T.S.K. Dissecting Candida Pathobiology: Post-Translational Modifications on the Candida Tropicalis Proteome. Omi. A J. Integr. Biol. 2018, 22, 544-552. [CrossRef]

55. Perez-Riverol, Y.; Csordas, A.; Bai, J.; Bernal-Llinares, M.; Hewapathirana, S.; Kundu, D.J.; Inuganti, A.; Griss, J.; Mayer, G.; Eisenacher, M.; et al. The PRIDE Database and Related Tools and Resources in 2019: Improving Support for Quantification Data. Nucleic Acids Res. 2019, 47, D442-D450. [CrossRef] [PubMed]

56. Yu, C.-S.; Lin, C.-J.; Hwang, J.-K. Predicting Subcellular Localization of Proteins for Gram-Negative Bacteria by Support Vector Machines Based on N -Peptide Compositions. Protein Sci. 2004, 13, 1402-1406. [CrossRef] [PubMed]

57. Yu, C.-S.; Chen, Y.-C.; Lu, C.-H.; Hwang, J.-K. Prediction of Protein Subcellular Localization. Proteins Struct. Funct. Bioinforma. 2006, 64, 643-651. [CrossRef]

58. Yu, N.Y.; Wagner, J.R.; Laird, M.R.; Melli, G.; Rey, S.; Lo, R.; Dao, P.; Sahinalp, S.C.; Ester, M.; Foster, L.J.; et al. PSORTb 3.0: Improved Protein Subcellular Localization Prediction with Refined Localization Subcategories and Predictive Capabilities for All Prokaryotes. Bioinformatics 2010, 26, 1608-1615. [CrossRef]

59. Savojardo, C.; Martelli, P.L.; Fariselli, P.; Profiti, G.; Casadio, R. BUSCA: An Integrative Web Server to Predict Subcellular Localization of Proteins. Nucleic Acids Res. 2018, 46, W459-W466. [CrossRef]

60. Kanehisa, M.; Furumichi, M.; Tanabe, M.; Sato, Y.; Morishima, K. KEGG: New Perspectives on Genomes, Pathways, Diseases and Drugs. Nucleic Acids Res. 2017, 45, D353-D361. [CrossRef] [PubMed]

61. Gupta, A.; Kapil, R.; Dhakan, D.B.; Sharma, V.K. MP3: A Software Tool for the Prediction of Pathogenic Proteins in Genomic and Metagenomic Data. PLoS ONE 2014, 9, e93907. [CrossRef] [PubMed]

62. Kumar, S.; Lata, K.S.; Sharma, P.; Bhairappanavar, S.B.; Soni, S.; Das, J. Inferring Pathogen-Host Interactions between Leptospira Interrogans and Homo Sapiens Using Network Theory. Sci. Rep. 2019, 9, 1434. [CrossRef] [PubMed] 